\title{
The 2016-2017 eruption of Bogoslof volcano, Alaska: preface to the special issue
}

\author{
Christopher F. Waythomas ${ }^{1}$ (D) John J. Lyons ${ }^{1} \cdot$ David Fee $^{2} \cdot$ Kristi L. Wallace $^{1}$ \\ Received: 11 March 2019 / Accepted: 24 May 2019 / Published online: 26 July 2019 \\ (C) This is a U.S. government work and not under copyright protection in the U.S.; foreign copyright protection may apply 2019
}

The Alaska Volcano Observatory (AVO) and partners have established a tradition of reporting on the results of significant volcanic unrest in Alaska by seeking to compile collected works that describe the overall nature of eruptive activity at individual volcanoes. There are typically multiple novel and noteworthy aspects of each eruptive event that are of broad interest to the volcanological community.

There are more than 50 historically active volcanoes within the Aleutian arc, most of which are ice- and snow-covered stratovolcanoes, and AVO has a long record of monitoring and evaluating subaerial eruptive activity at these volcanoes. Submarine volcanism in the Aleutian arc is much less common, and until the 2016-2017 eruption of Bogoslof volcano, AVO had never monitored, studied, or evaluated a significant submarine eruption. This special issue of Bulletin of Volcanology is a first for AVO in that we report on our initial research results from a 9-month long, predominantly submarine eruption of Bogoslof volcano.

Editorial responsibility: N. Fournier

This paper constitutes part of a topical collection:

The 2016-17 shallow submarine eruption of Bogoslof volcano, Alaska

Christopher F. Waythomas

cwaythomas@usgs.gov

John J. Lyons

jlyons@usgs.gov

David Fee

dfee1@alaska.edu

Kristi L. Wallace

kwallace@usgs.gov

1 Alaska Volcano Observatory, U.S. Geological Survey, 4230 University Drive, Suite 100, Anchorage, AK 99508, USA

2 Alaska Volcano Observatory and Geophysical Institute, University of Alaska-Fairbanks, Fairbanks, AK 99775, USA
Bogoslof volcano is an isolated, almost entirely submarine stratovolcano in the southern Bering Sea of Alaska (53.9272 $\mathrm{N}, 168.0344^{\circ} \mathrm{W}$ ). The volcano is situated about $50 \mathrm{~km}$ north of the main volcanic front and has thus been described as a back-arc volcano. The Bogoslof cone has a basal diameter of about $18 \mathrm{~km}$, flanking slopes of 12-14 degrees and about $1700 \mathrm{~m}$ of relief. The volcano has a volume of about $130 \mathrm{~km}^{3}$ but only a small portion of the edifice $(<0.06 \%)$ extends above sea level. The highest point on Bogoslof Island is about $100 \mathrm{~m}$ above sea level.

In early May 1796, the Russian Orthodox Missionary Priest Ivan Veniaminov observed an island near the present location of Bogoslof Island around the day known as the feast day of Pope St. John I, or St. John's Day, and thus the island received the name "Joanna Bogoslova" (or John the Theologian's Island). In the present context, Bogoslof volcano is an informal name that refers to the submarine edifice and its surface expression that today includes both Bogoslof Island and Fire Island, a small isolated sea stack about $800 \mathrm{~m}$ north of modern-day Bogslof Island. Bogoslof has been visited by a number of noteworthy mariners and scientists in historic time, including Captain James Cook, the Harriman Expedition to Alaska (including G.K. Gilbert and John Muir), and Thomas A. Jaggar (the founder of the Hawaiian Volcano Observatory).

Bogoslof volcano has had at least nine reported historical eruptive periods since 1796, and at least seven were characterized by extrusion of the submarine to subaerial lava domes of basalt to basaltic andesite composition. Many of the historical eruptions have produced ash clouds, and measurable ashfall was documented in 1883, 1907, and 2017 on the nearest islands to the south of Bogoslof (Umnak and Unalaska Islands). Prior to 2016, none of the historical eruptions were particularly well studied (Waythomas and Cameron, 2018), and the most recent study of the geology of Bogoslof Island was based on a single day of fieldwork in 1947 (Byers, 1959).

The 2016-2017 eruption posed a formidable monitoring challenge to AVO because no geophysical equipment was located on the island itself. In addition, it was not possible to 
make direct observations of the ongoing eruptive activity or visit the island due to its remote location and hazardous conditions. Thus, to monitor the unrest AVO had to rely on seismic and infrasound data recorded by networks on Umnak and Unalaska Islands (about 40 and $60 \mathrm{~km}$ south and east of Bogoslof, respectively) and other more distal networks. This information was supplemented with satellite data of various types, occasional airborne observations, and remote detection of volcanic plume lightning - a characteristic feature of several eruptive events. The start of the eruption is not known, but the activity was occurring by December 12-14, 2016, and the last explosive eruption occurred on August 30, 2017; there were at least 70 detected explosive events during this period. Almost all of the Bogoslof eruptions originated at shallow submarine vents ( $<150-\mathrm{m}$ water depth) complicating AVO's monitoring efforts. Seawater, therefore, played an important role in the eruptive process and hazards.

In this special issue, readers will encounter treatments of the seismology (Haney et al.; Tepp et al.; Searcy et al.), hydroacoustics (Tepp et al.), infrasound (Fee et al.; Lyons et al.; Schwaiger et al.), geology, geomorphology and petrology (Loewen et al.; Waythomas et al.), volcanic lightning (Van Eaton et al.; Haney et al.), $\mathrm{SO}_{2}$ emissions (Lopez et al.), and remote sensing of volcanic clouds (Schneider et al.) associated with the 2016-2017 Bogoslof eruption. Of the 70 explosive events, samples of ash were only obtained on three occasions and the only visit to the island occurred almost a year after the eruption ended. The collection of works represented here is thus gleaned mainly from geophysical and remote sensing data. A common theme in all of the research contributions is the remote detection of unrest and its interpretation in the context of explosive shallow submarine volcanism. The aim of this collection is to expand the knowledge base pertinent to shallow submarine eruptive activity, and to complement existing treatments of submarine phreatomagmatic eruptions at Surtsey, Iceland (Thorarinsson et al., 1964; Kokelaar, 1983), Taal, Phillippines (Moore et al., 1966), Capelinhos, Azores (Waters and Fisher, 1971), and others (White et al., 2015).

As with many of the historical eruptions monitored and evaluated by AVO, many more individuals that are represented by the contributing authors to this volume had important and valuable roles during the 2016-2017 Bogoslof activity.

Acknowledgments We wish to thank all who participated in the eruption response and in the preparation of this volume. The Alaska Volcano Observatory is a cooperative program of the U.S. Geological Survey, the University of Alaska-Fairbanks Geophysical Institute, and the Alaska Division of Geological and Geophysical Surveys.

\section{References}

Byers FM Jr (1959) Geology of Umnak and Bogoslof Islands, Aleutian Islands, Alaska. US Geol Surv Bull 1028-L:267-369

Kokelaar BP (1983) The mechanism of Surtseyan volcanism. J Geol Soc Lond 140:939-944

Moore JG, Nakamura K, Alcaraz A (1966) The 1965 eruption of Taal Volcano. Science 151:955-960

Thorarinsson S, Einarsson T, Sigvaldason G, Elisson G (1964) The submarine eruption off the Vestmann Islands 1963-64. A preliminary report. Bull Volcanol 27:435-445

Waters AC, Fisher RV (1971) Base surges and their deposits: Capelinhos and Taal Volcanoes. J Geophys Res 76(23):5596-5614. https://doi. org/10.1029/JB076i023p05596

White JD, Schipper CI, Kano K (2015) Submarine explosive eruptions. In: Sigurdsson H et al (eds) The encyclopedia of volcanoes, 2 nd edn. Academic Press, London, pp 553-569

Waythomas CF, Cameron CE (2018) Historical eruptions and hazards at Bogoslof volcano. US Geological Survey Scientific Investigations Report 2018-5085, p 42 